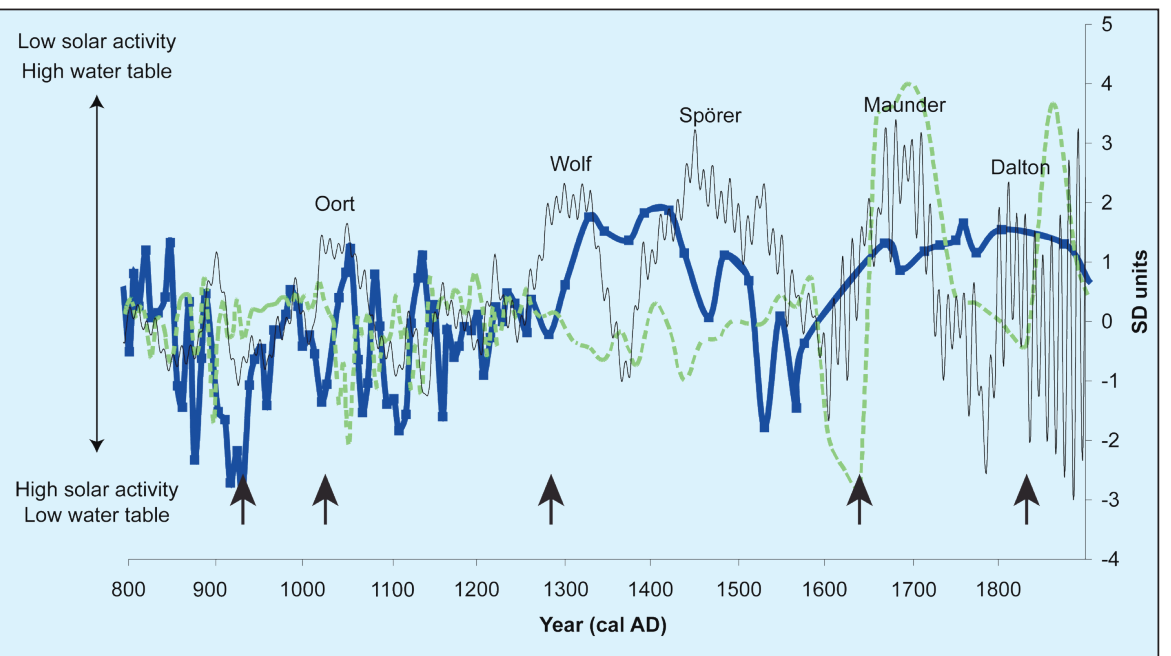

Figure 2: Focus Interval III (cal a AD 800-1800) of the ACCROTELM project, showing proxy-climate data from the Danish bog site: Blue line $=$ normalized testate amoebae water table reconstruction (inverted); Green dashed line $=$ plant macrofossil Dupont wetness index; Gray line $=$ normalized ${ }^{14} \mathrm{C}$ relative production rate (q). Arrows indicate start of significant rises in water table. Historical solar minima are indicated. Figure adapted from Mauquoy et al., 2008. For further discussion of solar-climate relationships in peat records, see van Geel and Mauquoy, this issue.

organic and elemental content (de Jong and research continues to extract a sepaet al., 2006; De Vleeschouwer et al., 2009), rate temperature signal from biomarkers.

\section{References}

Chambers, F.M., Daniell, J.R.G. and Brain, S.A., 2007a: Climate Change featuring the ACCROTELM project: dissemination of a European RTD project by film and DVD. In: Filho, W.L., Mannke, F. and Schmidt-Thome, P. (Eds) Information, Communication and Education on Climate Change-European Perspectives, Peter Lang, Frankfurt am Mein, 165-173.

Charman, D.J., Blundell, A. and ACCROTELM members, 2007: A new European testate amoebae transfer function for palaeohydrological reconstruction on ombrotrophic peatlands, Journal of Quaternary Science, 22: 209-221.

de Jong, R., et al., in press: Peatlands and climate. In: Dodson, J. (Ed.) Changing Climates, Earth Systems, and Society, Elsevier.

Magny, M. Peyron, 0 Gauthier, E, Rouèche, Y, Bordon, A, Billaud, Y, Chapron, E., Marguet, A., Pétrequin, P. and Vannière, B., 2009: Quantitative reconstruction of climatic variations during the Bronze and early Iron ages based on pollen and lake-level data in the NW Alps, France, Quaternary International, 200: 112-110.

Mauquoy, D., Yeloff, D., van Geel, B., Charman, D.J. and Blundell, A. 2008: Two decadally resolved records from north-west European peat bogs show rapid climate changes associated with solar variability during the mid-late Holocene, Journal of Quaternary Science, 23: 745-763.

For full references please consult:

http://www.pages-igbp.org/products/newsletters/ref2010_1.htm

\title{
Using peatland archives to test paleoclimate hypotheses
}

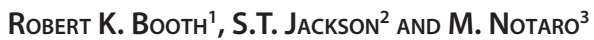

${ }^{1}$ Earth and Environmental Science Department, Lehigh University, Bethlehem, USA; robert.booth@lehigh.edu

${ }^{2}$ Department of Botany and Program in Ecology, University of Wyoming, Laramie, USA; ${ }^{3}$ Center for Climatic Research, University of Wisconsin,

Madison, USA

\section{A network of peatland surface-moisture reconstructions is providing a richly detailed, synoptic-scale perspective on past hydroclimate variability in many regions, well suited to investigate the spatial structure and dynamics of past hydroclimate changes.}

Synoptic networks of proxy records of hydroclimate variation provide an important means for identifying long-term relationships between oceanic forcing and continental-scale patterns of decadal- to centennial-scale drought variability, and for assessing responses of the coupled oceanatmosphere system to changes in external forcing. Tree-ring records provide the gold standard in this context, because of their demonstrated hydroclimatic sensitivity, temporal precision and accuracy, robustness of proxy inferences, and widespread distributions in space. However, tree-ring records are limited in temporal depth and spatial coverage, and inferences can be confounded by other factors, particularly in humid regions. Alternative archives are desirable to extend temporal depth, corroborate tree-ring inferences, and add complementary information and sensitivity at different time and spatial scales. Among the alternative archives are ombrotrophic peatlands, which are sensitive to hydroclimatic variation at decadal timescales, capable of sub-centennial chronological precision and accuracy, contain multiple paleohydrological and paleoclimatic proxies (Fig. 1a), and are widely distributed at mid- to high latitudes in the northern and southern hemispheres. Comparison of peatland proxies with instrumental records

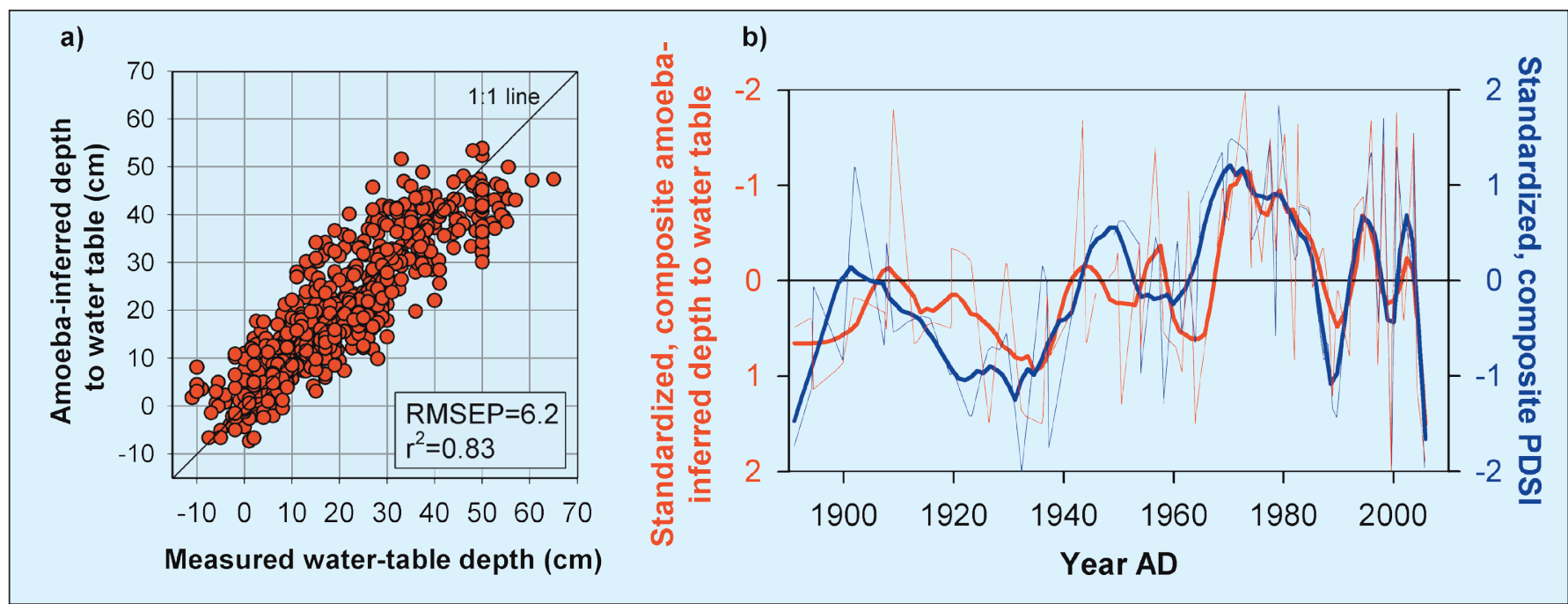

Figure 1: Validation of the hydrologic and climatic sensitivity of peatland surface-moisture reconstructions. a) Cross-validation of testate amoeba transfer function for mean annual water-table depth, based on over 650 samples from North American peatlands (modified from Booth, 2008). b) Comparison of a composite testate amoebae-inferred paleohydrological reconstruction (depth to water table) derived from three ${ }^{210} \mathrm{~Pb}$-dated peatland records (red lines) and instrumental records of Palmer Drought Severity Index (PDSl; blue lines) (data from Booth, 2010). Thick, solid lines show approximately decadal-scale smoothing of the composite datasets (thin lines). 
confirms the robustness and temporal precision of paleoclimatic inferences (Fig. 1b).

Over the past few years, significant advances have been made in our understanding of the response of peatland systems to climate changes, facilitating the climatic interpretation of peatland paleoenvironmental records. Peatland surface-moisture reconstructions generally reflect the length and severity of the summer moisture deficit, which in ombrotrophic peatlands is primarily controlled by summer precipitation (Charman, 2007; Charman et al., 2009). Temperature effects are secondary, manifested through evapotranspiration (Charman, 2007; Charman et al., 2009). Not surprisingly, good relationships exist between surface-moisture reconstructions and integrative hydroclimate indices such as the Palmer Drought Severity Index (PDSI) (Booth, 2010). However, because peatlands may undergo long-term developmental changes unrelated to climate (Charman et al., 2006), and are adaptive systems with internal processes that confer some degree of self-regulation (Dise, 2009), paleoclimate responses may not be recorded equally strongly at all temporal frequencies. For example, millennial and multi-millennial changes in surface moisture vary greatly among nearby sites in the United Kingdom (Charman et al., 2006), although shorterterm perturbations are generally coherent there and elsewhere in Europe and North America (Booth et al., 2006). Therefore, the hydroclimatic signal in peatland records may be most robust at multi-decadal to sub-millennial timescales.

\section{Investigating drought climatology}

An emerging network of peatland records in North America is providing new perspectives on moisture variability in humid regions, complementing and extending the tree-ring record from semi-arid regions, as well as hydroclimate histories derived from other natural archives. These efforts are motivated by the revelation that characteristic spatial modes of drought and precipitation variability, often with important centers of action in humid regions, have been driven in part by oscillations in sea-surface temperature (SST) anomalies sometimes spanning decades or more (Dai et al., 2004; McCabe et al., 2004, 2008; McCabe and Palecki, 2006; Seager et al., 2008; Woodhouse et al., 2009) (Fig. 2). Modeling efforts underscore the importance of these teleconnections, and are beginning to reveal potential underlying mechanisms (Sutton and Hodson, 2005, 2007; Seager et al., 2007). However, our knowledge of SST variability and associated teleconnections is primarily derived from a mere century of instrumen- a) 1 st EOF of annual PDSI (20\%)

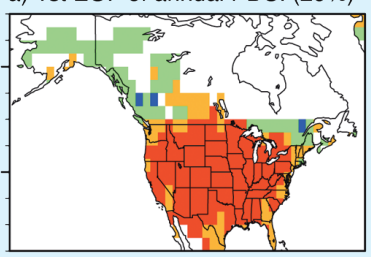

c) 2nd EOF of annual PDSI (12\%)

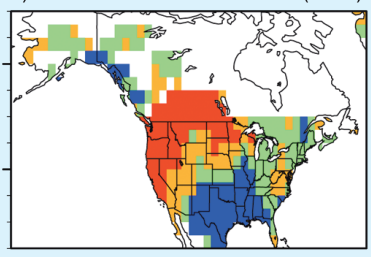

e) 3rd EOF of annual PDSI (10\%)

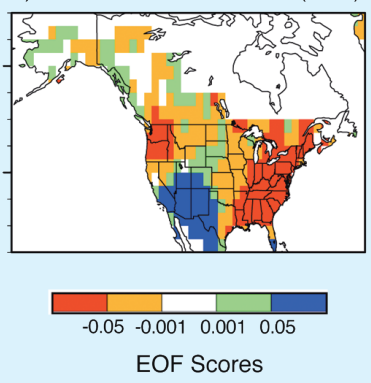

b) SST correlations with 1st EOF

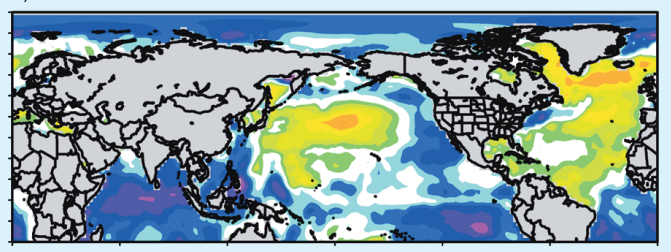

d) SST correlations with 2nd EOF

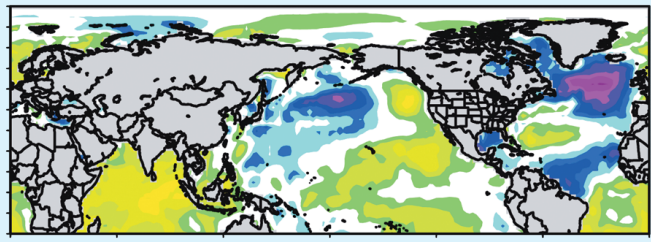

f) SST correlations with 3rd EOF

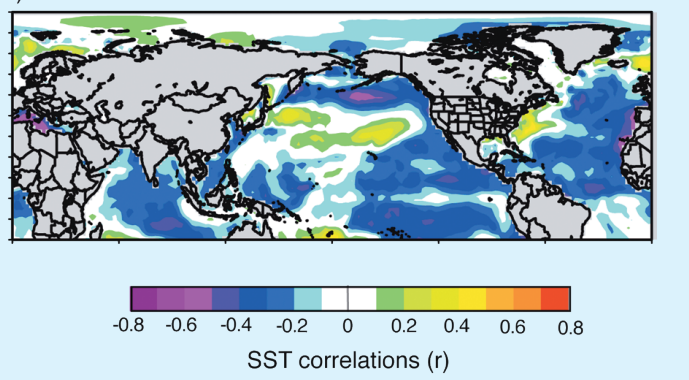

Figure 2: Natural modes of variability in low-pass filtered Palmer Drought Severity Index (PDSI) data from North America over the last century (1900-1998) as indicated by Empirical Orthogonal Function (EOF) analysis (a, c, e) (methods detailed in Booth et al., 2006). Percent variance explained by each EOF is indicated. Correlations between sea surface temperatures (SSTS) and the three dominant EOFs indicate SST patterns associated with dominant modes of hydroclimate variability $(\boldsymbol{b}, \boldsymbol{d}, \boldsymbol{f})$. A network of peatland records has been designed to test the hypothesis that similar modes of drought variability have affected North American hydroclimate during the past several thousand years, with ongoing work in the Great Lakes region, the Pacific Northwest, and northeastern North America.

tal records, and rising global temperatures are expected to alter the oceanic forcing of drought patterns in the coming decades (Jansen et al., 2007). In addition, the relative importance of oceanic forcings (i.e., Atlantic vs Pacific influences) on North American hydroclimate is still unclear (Sutton and Hodson, 2005; McCabe and Palecki, 2006; Cook et al., 2007; Goodrich, 2007; Graham et al., 2007; Seager et al., 2007; Feng et al., 2008; McCabe et al., 2008), as are relationships to synoptic modes of atmospheric circulation (Trouet et al., 2009; Helama et al., 2009) and external forcing (i.e., solar variability and volcanism). Delineation of past spatial modes of moisture variability, when interpreted in conjunction with the growing body of proxy SST records and estimates of changes in external forcing, provides a means to assess long-term dynamics of the coupled ocean-atmosphere system.

When viewed along with the tree-ring record and other natural archives, peatland reconstructions from the Great Lakes region of eastern North America reveal that many high-magnitude fluctuations in water balance during the past 3 ka were spatially extensive, extending from the western United States into eastern North America (Fig. 3; Cook et al., 2004; Mason et al., 2004; Booth et al., 2006; Shuman et al., 2009). Increased multidecadal- to cen- tennial-scale hydroclimate variability also characterized intervals with widespread drought (Fig. 3a). These widespread droughts may represent amplification or persistence of modes of decadal- to multidecadal hydroclimate variability similar to that of the last century (Fig. 2). For example, peatland records clearly indicate that Medieval Climate Anomaly (MCA) droughts, which have been well documented in the western US and Great Plains (central North America) (e.g., Cook et al., 2004; Mason et al., 2004; Daniels and Knox, 2005; Sridhar et al., 2006; Meko et al., 2007; Miao et al., 2007), also extended deep into the Great Lakes region (Booth et al., 2006; Shuman et al., 2009) (Fig. 3a). The widespread pattern of drought is similar to a mode of variability experienced during the $20^{\text {th }}$ century (Fig. 2a), although more records are needed to fully test this hypothesis, particularly from humid regions at mid-to high-latitudes.

Tree-ring based reconstructions of PDSI from the Great Lakes region do not clearly record the MCA droughts (Herweijer et al., 2007); therefore, hypotheses on the mechanisms underlying these events have tended to focus on atmospheric and ocean dynamics that induce drought in western North America only, such as prolonged La Niña-like conditions in the tropical Pacific (Cook et al., 2004, 2007). Although 


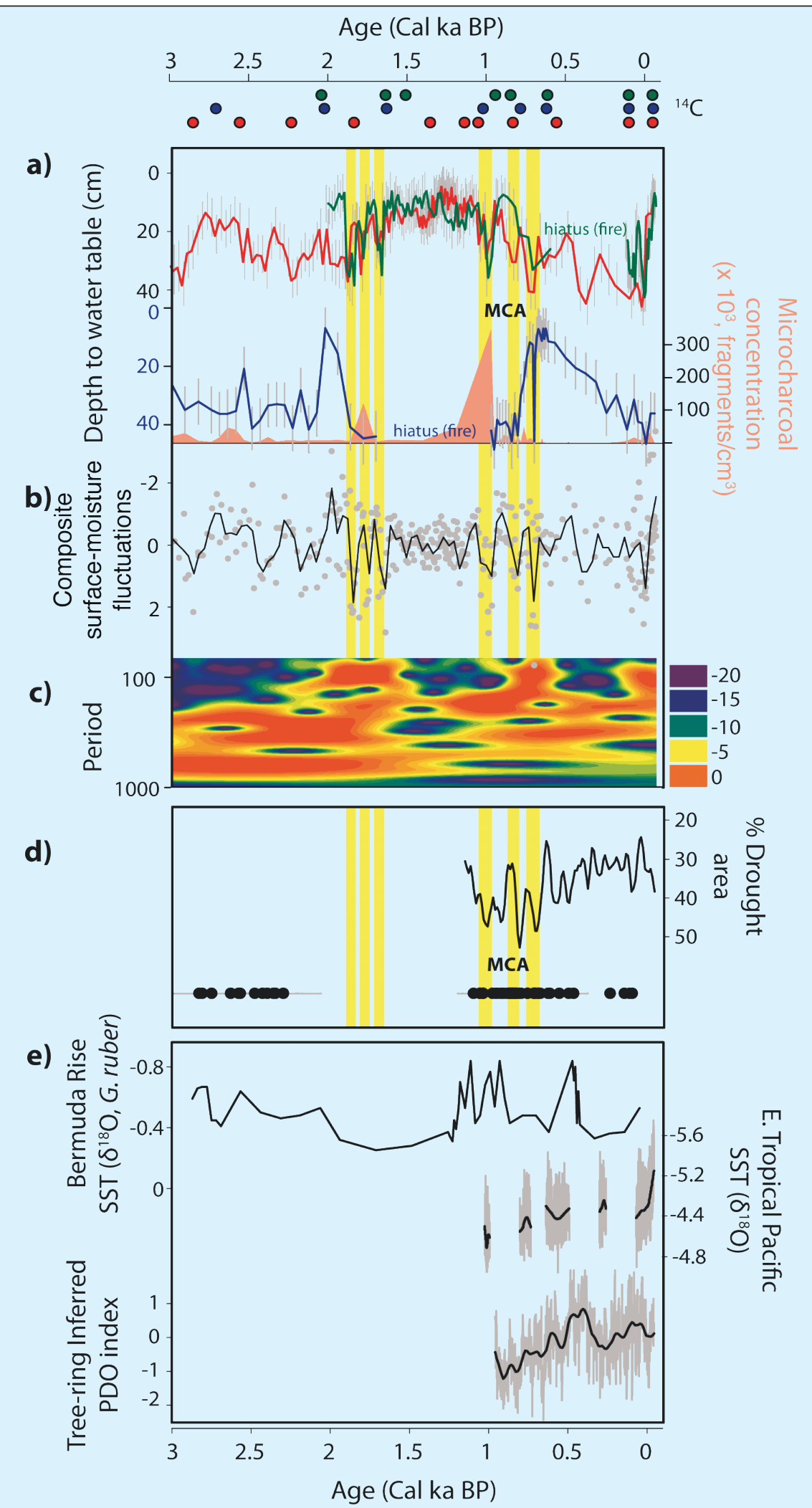

Figure 3: a) Ombrotrophic peatland archives of late Holocene environmental variability in the Great Lakes region (eastern N. America). Green: Hole Bog in north central Minnesota, Blue: Irwin Smith Bog in northeast lower Michigan, Red: Minden Bog in southeast Michigan (Booth et al., 2006, unpublished). Radiocarbon dates indicated at top and color-coded to match sites. All reconstructions based on testate amoebae (see Booth and Jackson, 2003; Booth et al., 2006). Bootstrapped error bars in gray ( $n=1000)$. Yellow bars indicate high-magnitude, multidecadal drought events that occurred at all three sites. A peat fire at $\sim 1 \mathrm{ka} \mathrm{BP} \mathrm{removed} \mathrm{lower} \mathrm{peat} \mathrm{from} \mathrm{Irwin} \mathrm{Smith} \mathrm{Bog,}$ micro-charcoal concentrations are shown in pink. b) Composite record from the three sites developed by removing the long-term patterns that may be unrelated to climate (Charman et al., 2006), standardizing the three datasets (gray dots; standardized units), and calculating a 50-year moving average (black line). c) Wavelet analysis of composite record highlighting increased centennial and sub-centennial variability during drought intervals.d) Tree-ring record of drought in western USA (black line; Cook et al., 2004) and records of dune activity (e.9., aeolian sand movement) on the Great Plains (black dots are activity dates with error bars; Goble et al., 2004; Mason et al., 2004: Miao et al., 2007), highlighting the widespread droughts of the Medieval Climate Anomaly (MCA). e) Atlantic (Keigwin, 1996) and Pacific (Cobb et al., 2003; MacDonald and Case, 2005) proxy SST records, from which preliminary patterns suggest that the MCA droughts may have resulted from the combined influence of anomalous Atlantic and Pacific SSTs, perhaps also linked to changes in the North Atlantic Oscillation (Trouet et al., 2009: Helama et the eastward and northward extent of the droughts in North America is still unclear, the occurrence of significant droughts in the peatland records from the Great Lakes suggests that additional hypotheses regarding mechanisms and dynamics should be explored, including modulation of Pacific influences by SST variability in the Atlantic source region. Recently, MCA modeling efforts have started to incorporate this idea (Seager et al., 2007; Feng et al., 2008). For example, using a set of modeling experiments, Feng et al. (2008) found that cold eastern Tropical Pacific SST anomalies could explain the intensity of the MCA droughts, a warm North Atlantic could regulate the geographic extent of the droughts, and the combined influence of SST anomalies in both basins was necessary to explain MCA drought severity and persistence. Similar patterns have been associated with widespread mid-continental drought during the past century (Fig. 2a, b) (McCabe et al., 2004, 2008; Booth et al., 2006). Continued development of the peatland network is currently underway in North America and in other circum-boreal regions of the Northern Hemisphere, and coupled with analyses of instrumental data, data-model comparisons, and dynamic modeling experiments will allow critical testing of this and other hypotheses on the mechanisms and dynamics of widespread, prolonged drought.

\section{Acknowledgements}

Research supported by grants from the National Science Foundation to Booth (EAR-0902441, ATM-0625298) and Jackson (ATM-0402660).

\section{Data}

Minden Bog testate amoeba data available from NOAA Paleoclimatology database (www.ncdc. noaa.gov/paleo/pubs/booth2003/booth2003. html). Other data will be made available via this database and the Neotoma Paleoecology Database (www.neotomadb.org/).

\section{References}

Booth, R.K., 2010: Testing the climate sensitivity of peat-based paleoclimate reconstructions in mid-continental North America, Quaternary Science Reviews, 29: 720-731. doi: 10.1016/j.quascirev.2009.11.018

Booth, R.K., Notaro, M., Jackson, S.T. and Kutzbach, J.E., 2006: Widespread drought episodes in the western Great Lakes region during the past 2000 years: geographic extent and potentia mechanisms, Earth and Planetary Science Letters, 242: 415-427.

Charman, D.J., Barber, K.E., Blaauw, M., Langdon, P.G., Mauquoy, D. Daley, T.J., Hughes, P.D.M. and Karofeld, E., 2009: Climate drivers for peatland palaeoclimate records, Quaternary Science Reviews, 28: 1811-1819.

Feng, S., Oglesby, R.J, Rowe, C.M. Loope, D. B. and Hu, 0, 2008: Atlantic and Pacific SST influences on Medieval drought in North America simulated by the Community Atmospheric Model, Journal of Geophysical Research, 113: D11101, doi:10.1029/2007JD009347.

McCabe, G.J., Betancourt, J.L., Gray, S.T., Palecki, M.A. and Hidalgo, H.G., 2008: Associations of multi-decadal sea-surface temperature variability with US drought, Quaternary International, 188: 31 40.

For full references please consult:

http://www.pages-igbp.org/products/newsletters/ref2010_1.htm| 


\section{R.K. Booth, S.T. Jackson and M. Notaro}

Booth, R.K., 2008: Testate amoebae as proxies of mean annual water-table depth in Sphagnum-dominated peatlands of North America, Journal of Quaternary Science, 23: 43-57.

Booth, R.K., 2010: Testing the climate sensitivity of peat-based paleoclimate reconstructions in mid-continental North America, Quaternary Science Reviews, 29: 720-731. doi: 10.1016/j.quascirev.2009.11.018

Booth, R.K. and Jackson, S.T. 2003. A high-resolution record of late Holocene moisture variability from a Michigan raised bog. The Holocene, 13: 865-878.

Booth, R.K., Notaro, M., Jackson, S.T. and Kutzbach, J.E., 2006: Widespread drought episodes in the western Great Lakes region during the past 2000 years: geographic extent and potential mechanisms, Earth and Planetary Science Letters, 242: 415-427.

Charman, D.J., 2007: Summer water deficit variability controls on peatland water-table changes: implications for Holocene palaeoclimate reconstructions, The Holocene, 17: 217-227.

Charman, D.J., Blundell, A., Chiverrell, R.C., Hendon, D.H. and Langdon, P.G, 2006: Compilation of non-annually resolved Holocene proxy climate records: stacked Holocene peatland palaeo-water table reconstructions from northern Britain, Quaternary Science Reviews, 25: 336-350.

Charman, D.J., Barber, K.E., Blaauw, M., Langdon, P.G., Mauquoy, D., Daley, T.J., Hughes, P.D.M. and Karofeld, E., 2009: Climate drivers for peatland palaeoclimate records, Quaternary Science Reviews, 28: 1811-1819.

Cobb, K.M., Charles, C.D., Cheng, H., and Edwards, R.L. 2003. E1 Nino-Southern Oscillation and tropical Pacific climate during the last millennium. Nature, 424: 271276.

Cook, E.R., Woodhouse, C., Meko, D.M. and Stahle, D.W., 2004: Long-term aridity changes in the western United States, Science, 306: 1015-1018.

Cook, E.R., Seager, R., Cane, M.A. and Stahle, D.W., 2007: North American drought: reconstructions, causes, and consequences, Earth-Science Reviews, 81: 93-134.

Dai, A., Trenberth, K.E. and Qian, T., 2004: A global dataset of Palmer Drought Severity Index for 1870-2002: relationships with soil moisture and effects of surface warming, Journal of Hydrometeorology, 5: 1117-1130.

Daniels, J.M. and Knox, J.C., 2005: Alluvial stratigraphic evidence for channel incision during the Mediaeval Warm Period on the central Great Plains, USA, The Holocene, 15: 736-747.

Dise, N.B, 2009: Peatland responses to global change, Science, 326: 810-811.

Feng, S., Oglesby, R.J., Rowe, C.M, Loope, D.B. and Hu, Q., 2008: Atlantic and Pacific SST influences on Medieval drought in North America simulated by the Community Atmospheric Model, Journal of Geophysical Research, 113, D11101, doi:10.1029/2007JD009347.

Goble, R.J., Mason, J.A., Loope, D.B., and Swinehart, J.B. 2004. Optical and radiocarbon ages of stacked paleosols and dune sands in the Nebraska Sand Hills, USA, Quaternary Science Reviews, 23: 1173-1182.

Goodrich, G.B., 2007: Multidecadal climate variability and drought in the United States, Geography Compass, 1/4: 713-738.

Graham, N.E., et al., 2007: Tropical Pacific - mid-latitude teleconnections in medieval times, Climatic Change, 83: 241-285.

Helama, S., Merilainen, J. and Tuomenvirta, H., 2009: Multicentennial megadrought in northern Europe coincided with a global El Nino-Southern Oscillation drought pattern during the Medieval Climate Anomaly, Geology, 37: 175-178.

Herweijer, C., Seager, R., Cook, E.R. and Emile-Gray, J., 2007: North American droughts of the last millennium from a gridded network of tree-ring data, Journal of Climate, 20: 1353-1376.

Jansen, E., et al., 2007: Palaeoclimate. In: Solomon, S., et al. (Eds.) Climate Change 2007: The Physical Science Basis. Contribution of Working Group I to the Fourth Assessment 
Report of the Intergovernmental Panel on Climate Change, Cambridge University Press, Cambridge, United Kingdom and New York, USA.

Keigwin, L.D. 1996. The little ice age and medieval warm period in the Sargasso Sea. Science, 274: 1504-1508.

MacDonald, G.M. and Case. R.A. 2005. Variations in the Pacific Decadal Oscillation over the past millennium, Geophysical Research Letters, 32, L08703, doi:10.1029/2005GL022478.

Mason, J.A., Swinhart, J.B., Goble, R.J. and Loope, D.B., 2004: Late Holocene dune activity linked to hydrological drought, Nebraska Sand Hills, USA, Holocene, 14: 209-217.

McCabe, G.J. and Palecki, M.A., 2006: Multidecadal climate variability of global lands and oceans, International Journal of Climatology, 849-865.

McCabe, G.J., Palecki, M. and Betancourt, J.L., 2004: Pacific and Atlantic Ocean influences on multidecadal drought frequency in the United States, Proceedings of the National Academy of Science, 101: 4136-4141.

McCabe, G.J., Betancourt, J.L., Gray, S.T., Palecki, M.A. and Hidalgo, H.G., 2008: Associations of multi-decadal sea-surface temperature variability with US drought, Quaternary International, 188: 31-40.

Meko, D.M., Woodhouse, C.A., Baisan, C.A., Knight, T., Lukas, J.J., Hughes, M.K. and Saltzer M.W., 2007: Medieval drought in the upper Colorado River Basin, Geophysical Research Letters, 34: L10705, doi:10.1029/2007GRL029988.

Miao, X., Mason, J.A., Swinehart, J.B., Loope, D.B., Hansen, P.R., Goble, R.J. and Liu, X., 2007: A 10,00 year record of dune activity, dust storms, and severe drought in the central Great Plains, Geology, 35: 119-122.

Seager, R., Graham, N., Herweijer, C., Gordon, A.L., Kushnir, Y. and Cook, E., 2007: Blueprints for Medieval hydroclimate, Quaternary Science Reviews, 26: 2322-2336.

Seager. R., Kushnir, Y., Ting, M., Case, M., Naik, N. and Miller, J., 2008: Would advance knowledge of 1930s SSTs have allowed prediction of the dust bowl drought? Journal of Climate, 21: 3261-3281.

Shuman, B., Henderson, A.K., Plank, C., Stefanova, I. and Ziegler, S.S., 2009: Woodland-toforest transition during prolonged drought in Minnesota after ca. AD 1300, Ecology, 90: 2792-2807.

Sridhar, V., Loope, D.B., Swinehart, J.B., Mason, J.A., Oglesby, R.J. and Rowe, C.M., 2006: Large wind shift on the great plains during the Medieval Warm Period, Science, 313: 345-347.

Sutton, R.T. and Hodson, D.L.R., 2005: Atlantic Ocean forcing of multidecadal variations in North American and European summer climate, Science, 309:115-118.

Sutton, R.T. and Hodson, D.L.R., 2007: Climate response to basin-scale warming and cooling of the North Atlantic Ocean, Journal of Climate, 20: 891-907.

Trouet, V., Esper, J., Graham, N.E., Baker, A., Scourse, J.D. and Frank, D.C., 2009: Persistent positive North Atlantic oscillation mode dominated the Medieval Climate Anomaly, Science, 324: 78-80.

Woodhouse, C.A., Russell, J.L. and Cook, E.R., 2009: Two modes of North American drought from instrumental and paleoclimatic data, Journal of Climate, 22: 4336-4347. 